WARSZTATY Z GEOGRAFII TURYZMU

ISBN 978-83-7969-262-0 $\quad$ s. 313-327

http://dx.doi.org/10.18778/7969-262-0.20

Jolanta WOJCIECHOWSKA

Uniwersytet Łódzki

Amina UAISOWA

Uniwersytet im. Al-Farabiego w Ałmaty

\title{
MOŻLIWOŚCI ROZWOJU AGROTURYSTYKI W KAZACHSTANIE
}

\section{Wprowadzenie}

W świecie agroturystyka ma co najmniej kilkudziesięcioletnią historię. Pojawiła się w europejskich społecznościach i stąd rozpoczęła się emisja jej idei na pozostałe części globu, w których rozwija się zgodnie ze specyfiką walorów przyrodniczych, rolnictwa oraz kultury określonych społeczności.

Celem autorek prezentowanego opracowania jest analiza możliwości rozwoju agroturystyki w Kazachstanie na tle zasobów turystycznych tego kraju oraz perspektyw wykorzystania niektórych doświadczeń pozyskanych w Polsce. Jest to więc praca przeglądowa, opierająca się na źródłach zastanych. Zasadnicza jej treść obejmuje trzy zagadnienia. Pierwsze odnosi się do charakterystyki zasobów przyrodniczych i antropogenicznych istotnych w rozwoju turystyki w Kazachstanie. Drugie dotyczy obecnej wielkości i struktury kazachskiej agroturystyki, zaś trzecie - wybranych polskich doświadczeń, ujętych $\mathrm{w}$ formie rekomendacji, mogących mieć znaczenie dla opisywanego kraju. 


\section{Przyrodnicze i społeczno-kulturowe zasoby Kazachstanu istotne $\mathrm{w}$ rozwoju turystyki}

Kazachstan jest położony w centrum kontynentu Eurazjatyckiego. Zdecydowana większość jego terytorium (88\%) leży w Azji, głównie Środkowej, oraz niewielka część w Europie (12\%, na zachód od rzeki Emby). Pod względem powierzchni $\left(2724,9\right.$ tys. $\left.\mathrm{km}^{2}\right)$ zajmuje dziewiąte miejsce na świecie. Graniczy $\mathrm{z}$ pięcioma państwami, spośród których najdłuższą granicę ma z Rosją (7548,1 km), a najkrótszą z Turkmenistanem $(426$ km). Na długości 2340 km graniczy z Morzem Kaspijskim. Kazachstan odznacza się tranzytowym położeniem, co ma duże znaczenie w rozwoju turystyki (Kazakhstan: Ulttik enciklopedia 2003).

Terytorium kraju jest nachylone z południa na północ oraz ze wschodu na zachód. Jego zachodnią część stanowią niziny, takie jak: Nadkaspijska i Turańska, rozdzielone południkowym pasmem niskich gór Mugodżarów (657 m n.p.m.) i płaskowyżem Ustiurt, stanowiące południowe przedłużenie Uralu. W północnej części leży Płaskowyż Turgajski, rozcięty doliną Bramy Turgajskiej, oraz południowy skraj Niziny Zachodniosyberyjskiej (Step Iszymski, dolina rzeki Irtysz). Centralną część zajmuje rozległe Pogórze Kazachskie z izolowanymi pasmami gór niskich i średnich o maksymalnej wysokości 1565 m n.p.m. Znaczną jego część stanowi step (o nazwie Sary Arka, czyli „Żółty Grzbiet”). Wschodnie i południowe pogranicze kraju zajmują wysokie góry, które stanowią 10\% ogółu terytorium. Są to zachodnie krańce Ałtaju i Tien Szanu (szczyt Chan-Tengri 7014 m n.p.m.). Pustynie i półpustynie stanowią aż $58 \%$ terytorium. Położone są głównie w południowej części kraju (np. Kyzył-kum, Mujun-kum, Sary Iszyk Otrau). Lasostepy i stepy (23\% terenu) występują głównie w części centralnej i północnej. Lasy spotyka się wysoko w górach, czyli na obrzeżach kraju. Należy zaznaczyć, że krajobraz Kazachstanu jest bardzo zróżnicowany. Można tu zobaczyć bezkresne stepy i pustynie, niskie wzgórza, ale także ośnieżone szczyty wysokich gór, lodowce (w Tien Szan), doliny, kaniony, turkusowe jeziora i alpejskie łąki (Kazakhstan: Ulttik enciklopedia 2003).

Klimat jest zdeterminowany położeniem tego kraju w głębi olbrzymiego kontynentu, z dala od oceanów, przez co nie docierają do niego masy morskiego powietrza. Kazachstan leży w strefie klimatu umiarkowanego suchego, skrajnie kontynentalnego, który cechuje się suchym powietrzem, małą ilością opadów (100-500 mm rocznie, w centralnej części praktycznie 
one nie występują) oraz dużymi wahaniami temperatury powietrza w ciągu dnia i roku. Średnie amplitudy temperatur dla lata wynoszą do $+40^{\circ} \mathrm{C}$, dla zimy do $-45^{\circ} \mathrm{C}$. Na północy panują długie, ostre zimy i krótkie lata, zaś na południu krótkie zimy i długie, gorące lata. Prawie całe terytorium charakteryzuje się silnymi wiatrami.

Kazachstan jest wyjątkowy z uwagi na przyrodę. Rośnie tutaj ponad 6 tys. gatunków roślin, z których 515 to endemiczne. Żyje ponad 100 gatunków ptaków i zwierząt, np. lamparty śnieżne, niedźwiedzie. Występują obszary, gdzie spotyka się niezwykłe połączenie gatunków roślin i zwierząt. Przykładem takim może być Jezioro Bałchasz, które w połowie jest wypełnione słoną wodą (część wschodnia), zaś w drugiej (część zachodnia) wodą dostarczaną przez dopływy rzeczne, co powoduje silne zróżnicowanie fauny i flory. Sieć rzeczna jest słabo rozwinięta, wiele jest rzek okresowych, które zanikają w piaskach pustyń. W Kazachstanie jest 48262 jeziora, które są rozmieszczone bardzo nierównomiernie. Najwięcej jest ich w północnej części kraju (45\%). Atrakcje przyrodnicze są chronione w różnych formach, z czego najwyższą rangę mają narodowe parki przyrody (12) i narodowe rezerwaty przyrody (10). Występują one głównie we wschodniej części kraju (Kazakhstan: Ulttik enciklopedia 2003).

Administracyjnie kraj podzielony jest na 14 prowincji i dwa miasta wydzielone: Ałmaty i Astana. W roku 2013 liczył nieco ponad 17 mln mieszkańców. Ludność jest bardzo zróżnicowana, zarówno etnicznie, jak i wyznaniowo. Kazachowie stanowiący rdzenną ludność liczą 63\% ogółu. Z pozostałych większych grup etnicznych należy wymienić: Rosjan (25\%), Ukrainców (2,9\%), Uzbeków (2,8\%), Niemców (1,5\%), Tatarów (1,5\%), Ujgurów (1,5\%) (www.kit.gov.kz). Islam wyznaje $47 \%$ społeczeństwa, natomiast prawosławie $44 \%$ (ogólnie chrześcijanie stanowią 47\%) ${ }^{1}$. Z podstawowymi wyznaniami wiążą się długie weekendy, które stanowią nawet po 5-6 dni wypoczynku (np. Kurban Ait lub prawosławne Boże Narodzenie).

Kazachstan należy do krajów najsłabiej zaludnionych na świecie. Średnia gęstość zaludnienia wynosi zaledwie 6 osób na 1 km². Wśród krajów Azji Środkowej jest najbardziej zurbanizowany. Ludność miejska stanowi więcej niż $60 \%$ ogółu mieszkańców. Największym miastem jest Ałmaty, zwanym

${ }^{1}$ Katolikami są przede wszystkim Niemcy oraz potomkowie deportowanych tu za czasów Związku Radzieckiego Polaków, Białorusinów, Estończyków. 
południową stolicą, liczącym około $1,5 \mathrm{mln}$ ludzi². Do dużych miast należy Astana (750 tys. mieszkańców) i Szymkent (650 tys.). Ogółem w Kazachstanie jest 86 miast, z czego najwięcej znajduje się w regionie Karaganda (11 miast) (www.kit.gov.kz). Odnotowano też 6936 osiedli wiejskich, w których mieszka 7,6 mln ludzi. Osiedla te dzieli się na dwie grupy: o wysokim potencjale rozwoju, których jest 1310 i o średnim potencjale, których jest 5192. Więcej niż połowa wiejskich osiedli odznacza się małą liczbą mieszkańców, tj. poniżej 500 osób - mieszka w nich zaledwie 9,7\% ludności wiejskiej. Dla nich szans rozwoju upatruje się w agroturystyce (Programma... 2013).

W Kazachstanie jest 36300 różnych przedsiębiorstw rolnych oraz 30800 prywatnych (chłopskich) gospodarstw. Uprawia się zboża (pszenicę, jęczmień, owies) i ziemniaki, a z roślin przemysłowych - głównie na południu kraju: bawełnę, tytoń, buraki cukrowe, ryż, a na zachodzie: kukurydzę i słoneczniki. Spory odsetek upraw prowadzonych jest na polach sztucznie nawadnianych. W hodowli dominują owce, bydło, konie, wielbłądy i kozy, a w okolicach większych miast - trzoda chlewna i drób (Programma... 2013).

Położenie Kazachstanu na skrzyżowaniu głównych arterii komunikacyjnych, w przeszłości wiodących między starożytnymi cywilizacjami świata, sprzyjało powstaniu tutaj powiązań gospodarczych, kulturowych i ideologicznych między Wschodem i Zachodem, Północą i Południem świata. Tym samym dało podstawę do ukształtowania bogatej historii i kultury obecnego narodu. Już w czasach starożytnych stepy Kazachstanu rozsławił Wielki Jedwabny Szlak, który jest także dzisiaj znakiem rozpoznawczym tego kraju www.e-history.kz/ru/contents/list/88). Bogactwo i różnorodność wartości kulturowych Kazachstanu można wyrazić np. w następujących liczbach:

- 25 tys. zabytków nieruchomych (historycznych, archeologicznych, architektonicznych i sztuki);

- 2560 tys. jednostek dóbr kultury znajdujących się w zbiorach i wystawach w 89 państwowych muzeach;

- 66840 mln woluminów książek, rzadkich rękopisów, publikacji zgromadzonych w 3495 państwowych bibliotekach (Kulturnoye nasledyie Kazakhstana 2005, s. 686).

2 W 1997 r. została przeniesiona stolica państwa z miasta Ałmaty, położonego na południu, do Akmoły, znajdującego się bliżej geograficznego centrum kraju, przemianowanego (później) na Astanę. 
Południowe regiony Kazachstanu są szczególnie bogate w zróżnicowane zabytki, takie jak: ruiny starożytnych osad, twierdze, mauzolea, kurhany, muzea i stanowiska archeologiczne. Opisane, w dużym zarysie, zasoby przyrodnicze i społeczno-kulturowe Kazachstanu wskazują na możliwości rozwoju bardzo różnych form turystyki.

\section{Skala i struktura turystyki w Kazachstanie}

Oficjalne statystyki pokazują stały wzrost turystyki. W roku 2011 zagraniczny ruch turystyczny liczył ponad 5,6 mln osób, a krajowy 5,3 mln. Natomiast przychód z usług świadczonych w branży turystycznej wyniósł $74 \mathrm{mld}$ tenge, tj. około $500 \mathrm{mln}$ dolarów albo $375 \mathrm{mln}$ euro (www.stat.kz). W okresie styczeń-czerwiec 2011 r. łączna liczba odwiedzających wzrosła o 45,9\%, w porównaniu do tego samego okresu w 2010 r., i wyniosła 9730 tys. osób (w 2010 r. 6669 tys.). Natomiast całkowity dochód branży turystycznej wzrósł o 5,1\% i wyniósł 34,9 mld tenge (w okresie styczeń-czerwiec 2010 r. 33,2 mld tenge). Liczba przedsiębiorstw turystycznych działających w Kazachstanie wynosi 1994, z czego 954 znajduje się w mieście Ałmaty (www. stat.kz).

W Kazachstanie wyróżnia się dwa główne produkty turystyczne, które wynikają z walorów turystycznych. Pierwszy odnosi się do turystyki kulturowej, szczególnie rozpowszechnionej wzdłuż Jedwabnego Szlaku (do niego zaliczany jest także ruch pielgrzymkowy). Drugi związany jest z szeroko rozumianą ekoturystyką, na którą składają się m.in.: safari, rafting, podglądanie ptaków, trekking, wspinaczka, polowania, wędkarstwo, turystyka przygodowa. Ten produkt jest rozwijany również na trasie Jedwabnego Szlaku, ale przede wszystkim w południowym i wschodnim Kazachstanie, zwłaszcza w regionie Akmola. Rozwojowi ekoturystyki poświęca się bardzo wiele uwagi. Jest ona rozumiana jako forma turystyki przyrodniczej, skupiającej turystów o zainteresowaniach poznawczych, naukowych i rekreacyjnych. Zasoby środowiska geograficznego, zwłaszcza wiele obszarów chronionych przyrodniczo, sprzyjają jej rozwojowi. W administracji państwowej dopracowano się terytorialnej struktury odpowiadającej za turystykę i rekreację na obszarach chronionych, prowadzenia edukacji ekologicznej oraz monitoringu ruchu turystycznego i stanu terenów rekreacyjnych wraz z działaniami rekultywacji zdegradowanych ekosystemów (www.eco-tourism.kz). 
Na terenie kraju jest 176 tras turystycznych (szlaków) wyznaczonych przez Komitet ds. Leśnictwa i Łowiectwa. Liczba odwiedzających chronione obszary przyrodnicze w 2010 r. wynosiła 538001 osób, w 2011 r. - 769 927, w 2012 r. - 811 150. Na obszarach przyrodniczych objętych ochroną znajduje się wiele urządzeń przeznaczonych dla turystów. Są to np. odpowiednio zagospodarowane punkty widokowe (86), pola biwakowe (168) czy parkingi dla pojazdów samochodowych (93). Turyści mogą korzystać z obiektów typu: kempingi, hotele, motele, schroniska turystyczne (ogółem 114), oraz gastronomicznych i handlowych (ogółem 102). Znaków i tablic informacyjnych umieszczonych jest 1148, a ruch turystyczny jest monitorowany w 103 punktach wejściowych (www.kit.gov.kz).

W krajowych planach rozwoju turystyki są uwzględniane założenia stawiane dla regionu Azji Środkowej. Do tego regionu oprócz Kazachstanu zaliczane są: Kirgistan, Uzbekistan, Turkmenistan, Xinjiang Uygur - Region Autonomiczny Chin. Wszystkie te kraje odznaczają się ciągłym ruchem turystów zagranicznych na Jedwabnym Szlaku oraz w segmencie turystyki przygodowej/przyrodniczej (www.e-history.kz).

Warto zaznaczyć, że Kazachowie słyną z gościnności, z którą wiąże się wiele starych zwyczajów oraz różnych tradycji pieczołowicie pielęgnowanych. Na przykład jest zwyczaj rezerwowania dla gości najsmaczniejszego pożywienia. Kazachska kuchnia słynie z wielu różnych przysmaków, szczególnie mięsnych, których podawanie na stół ma swój odpowiedni rytuał. Kazachowie wyróżniają trzy rodzaje gości. Pierwszy - to gość celowo zaproszony (arnay Konak), drugi - to przypadkowy podróżnik, „wysłany przez Boga" (kuday Konak), trzeci - nieoczekiwany (kydyrma Konak). Dla każdego z nich jest organizowana specjalna forma goszczenia. Naturalna gościnność, przekazywana przez wieki z pokolenia na pokolenie, stanowi wielki atut, zwłaszcza w rozwoju turystyki zagranicznej.

\section{Impulsy i efekty rozwoju agroturystyki w Kazachstanie}

W Kazachstanie na polu naukowym zaczęto o agroturystyce rozprawiać na początku XXI w. Tabela 1 przedstawia wykaz publikacji, które ukazały się w latach 2004-2013. Pierwsze pojedyncze prace pojawiły się w 2004 i 2005 r. i dotyczyły rozważań w zakresie możliwości aktywizacji obszarów wiejskich poprzez turystykę, a w szczególności poprzez enoturystykę (ERDAWLETOW, 
KOSHKINBAEWA 2004, 2005). Kolejne pojawiły się w 2008 r. i w nich autorzy operując terminem turystyka wiejska, analizują jej istotę oraz możliwości rozwoju w Kazachstanie (TUSUPBEKOWA 2008, UAISOWA 2008, UVAZHANOWA 2008). Termin ,"agroturystyka” pojawił się w publikacjach naukowych w roku 2010 (TEMIRBULATOWA 2010) i od tej pory jest często stosowany. Omawiane publikacje cechują się tym, że pokazują agroturystykę przede wszystkim w kontekście ogólnej teorii turystyki. Dużo rzadziej jest ona przedstawiana od strony praktycznych działan oraz uzyskanych efektów, takim przykładem jest artykuł dotyczący regionu Ałmaty (ABILDINOW, OSTAPENKO 2013). W publikacjach są ponadto prezentowane doświadczenia innych krajów, np. Polski (TEMIRBULATOWA 2010, WOJCIECHOWSKA, UAISOWA 2013).

Tabela 1. Publikacje naukowe z zakresu agroturystyki w Kazachstanie w latach 2004-2013

\begin{tabular}{|l|l|c|}
\hline \multicolumn{1}{|c|}{ Problematyka publikacji w świetle tytułu } & \multicolumn{1}{|c|}{ Autor } & $\begin{array}{c}\text { Rok } \\
\text { wydania }\end{array}$ \\
\hline $\begin{array}{l}\text { Enoturystyka jako nowy czynnik aktywizacji obszarów } \\
\text { wiejskich }\end{array}$ & $\begin{array}{l}\text { S.R. Erdawletow } \\
\text { U.T. Koshkinbaewa }\end{array}$ & 2004 \\
\hline Aktywizacja terenów wiejskich przez turystykę & $\begin{array}{l}\text { S.R. Erdawletow } \\
\text { U.T. Koshkinbaewa }\end{array}$ & 2005 \\
\hline Turystyka wiejska jako część ogólnej turystyki & G.M. Tusupbekowa & 2008 \\
\hline Czynniki rozwoju turystyki wiejskiej w Kazachstanie & A. Uaisowa & 2008 \\
\hline Perspektywy rozwoju turystyki wiejskiej w Kazachstanu & M.U. Uwazhanowa & 2008 \\
\hline Teoria i praktyka agroturyzmu na doświadczeniach polskich & M.A. Temirbulatowa & 2010 \\
\hline Rola przedsiębiorczości w rozwoju turystyki wiejskiej & S.K. Erzhanowa & 2011 \\
\hline Przesłanki rozwoju agroturyzmu & A. Uaisowa & 2012 \\
\hline Efektywność rozwoju agroturyzmu w Kazachstanie & A. Uaisowa & 2012 \\
\hline Uzasadnienie przesłanek rozwoju agroturystycznej farmy & A. Uaisowa & 2012 \\
\hline $\begin{array}{l}\text { Możliwości przyjęcia polskich doświadczeń w rozwoju } \\
\text { agroturystyki w Kazachstanie }\end{array}$ & $\begin{array}{l}\text { J. Wojciechowska } \\
\text { A. Uaisowa }\end{array}$ & 2013 \\
\hline $\begin{array}{l}\text { Socjalno-ekonomiczne rola oraz perspektywy rozwoju } \\
\text { agroturyzmu w Kazachstanie }\end{array}$ & Zh.N. Idyris & 2013 \\
\hline Rozwój agroturystyki w regionie Ałmaty & $\begin{array}{l}\text { P. Abildinow } \\
\text { I. Ostapenko }\end{array}$ & 2013 \\
\hline
\end{tabular}

Źródło: opracowanie własne.

W uwzględnionych $\mathrm{w}$ tab. 1 publikacjach używana jest terminologia, która jest stosowana w krajach europejskich oraz Wspólnoty Niepodległych Państw. Szczególnie popularne są definicje turystyki wiejskiej autorów rosyjskich, używających zamiennie określenia, takie jak: „turystyka agrarna” lub „agroturystyka”. M.B. BIRZHAKOW (2000, s. 217) uznaje turystykę wiejską za 
specjalistyczną. Podobnie uważa A.W. AlEKSANDROWA (2008, s. 494), która dostrzega ją jako odmianę turystyki ekologicznej, zapewniającą świadczenia zakwaterowania na wsi. W literaturze kazachskiej nie wypracowano do tej pory jednoznacznej definicji terminu ,"agroturystyka”. Na przykład A. UAISOWA $(2008$, s. 57) uważa, że jest to rodzaj działalności zorganizowanej na wsi, wykorzystującej jej walory rolne, naturalne, kulturowe, historyczne i inne.

Należy podkreślić, że w piśmiennictwie kazachskim termin ",agroturystyka" jest stosowany zamiennie z takimi, jak: „turystyka wiejska” czy „turystyka agrarna" oraz dominuje stanowisko integralności z turystyką ekologiczną, która jest bardzo popularna zarówno $\mathrm{w}$ administracyjnych planach rozwoju, jak i w badaniach naukowych. Używany jest też termin „wiejska ekoturystyka", jako połączenie obu wymienionych typów. Uznając ekologiczne odcienie agroturystyki przyjmuje się w kazachskiej literaturze, że jest ona jedną z najbardziej efektywnych gałęzi rolnictwa, zorientowaną społecznie, mającą pozytywny wpływ na życie mieszkańców wsi i obszarów wiejskich. W jej rozwoju upatruje się możliwości otwierania nowych miejsc pracy, przyciągnięcia młodych ludzi do wsi, poprawienia standardów życia ich mieszkańców, wprowadzenia stabilności społeczno-gospodarczej i promowania zrównoważonego rozwoju obszarów wiejskich. Turystom zaś oferuje możliwość poznania wiejskiej kultury.

Aby podkreślić specyficzny charakter kazachskiej agroturystyki, stanowiącej niejako symbiozę z turystyką ekologiczną, w dalszej części opracowania zdecydowano się stosować termin "agroekoturystyka”. W świetle polskiej literatury oznacza on wypoczynek u rolników uprawiających ziemię i produkujących żywność metodami ekologicznymi (ZARĘBA 2000, s. 51). W przypadku Kazachstanu należy go pojmować szerzej, jako formę turystyki bazującej na usługach oferowanych turystom przez rodziny rolnicze oraz innych mieszkańców obszarów wiejskich, które charakteryzują się zrównoważonym rozwojem (ekorozwojem), czyli odznaczających się najwyższymi walorami przyrodniczymi i krajobrazowymi, gdzie uczestnicy oraz organizatorzy (kreatorzy) tej turystyki w wyniku dużej świadomości ekologicznej i wrażliwości przyrodniczej przyczyniają się do rozwoju i ochrony obszaru.

Agroekoturystyka zaczęła przybierać zorganizowane formy w 2005 r., kiedy w Ałmaty powołano centrum informacji o zasobach ekoturystyki w Kazachstanie. Powstało ono w wyniku starań Fundacji Eurazja. Głównym celem działania centrum jest popularyzacja idei ekoturystyki oraz jej promowanie na rynku turystycznym, krajowym i zagranicznym. Cel ten jest 
realizowany m.in. poprzez szeroką akcję reklamową określonych regionów oraz dostarczanie turystom i osobom zainteresowanym wielu informacji, a także możliwości rezerwacji i uczestniczenia w różnorodnych wycieczkach lub pobytach na wybranych obszarach.

Całość działań centrum opiera się na programie rozwoju i promocji turystyki ekologicznej, uwzględniającym współpracę z lokalnymi społecznościami. W tym celu w terenie zorganizowano sieć gościnnych domów przygotowanych do przyjmowania turystów. Na te potrzeby pracownicy centrum przeszkolili z określonych obszarów dostawców usług turystycznych (72 osoby), w tym właścicieli domów gościnnych i innych koordynatorów takich usług. Opracowano liczne materiały instruktażowe, takie jak: przewodniki turystyczne, informatory wymogów dla gościnnych kwater, arkusze ocen dla kwater ubiegających się o certyfikację, wykaz certyfikowanych gościnnych domów oraz rozmówki angielsko-rosyjsko-kazachskie dla ekoturystów. Domy gościnne, ogólnie prezentujące dość proste warunki pobytu, były celowo dobierane także w zakresie takich aspektów, jak: ciekawe otoczenie, urozmaicone pięknymi krajobrazami, bogate w obiekty kulturowe, przyrodnicze, o tradycyjnym wiejskim sposobie życia mieszkańców, oferujących bezgraniczną gościnność (www.eco-tourism.kz).

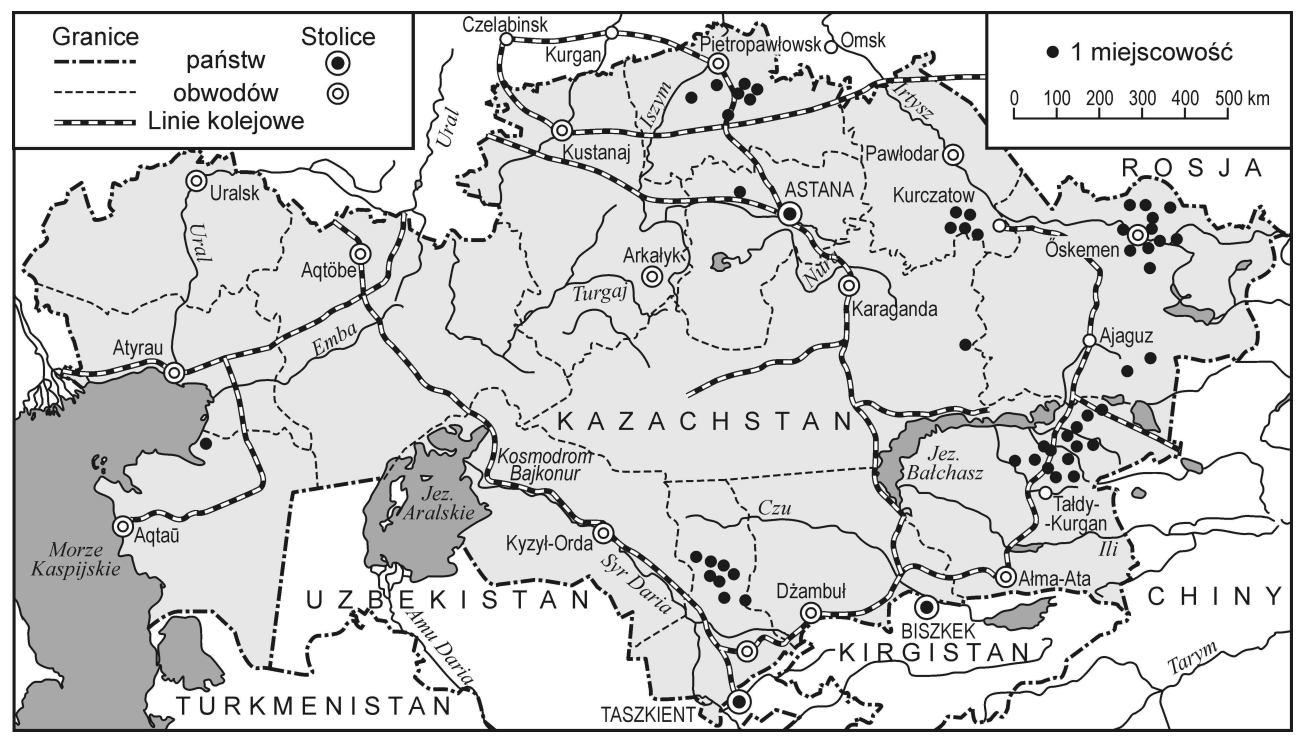

Rys. 1. Rozmieszczenie w Kazachstanie agroekoturystycznych miejscowości (ekosajt) Źródło: opracowanie własne na podstawie www.eco-tourism.kz 
Efekty działalności opisywanego centrum przedstawia rys. 1 oraz tab. 2, z których można wyczytać wielkość, strukturę i rozmieszczenie agroekoturystyki w Kazachstanie. Zlokalizowana jest ona w trzech głównych (ekonomicznych) regionach kraju: południowym, wschodnim i północnym, tam gdzie występuje infrastruktura turystyczna oraz walory turystyczne, zwłaszcza przyrodnicze i krajobrazowe. Na tych obszarach znajdują się piesze szlaki, trasy konne, rowerowe, można uprawiać wędkarstwo, rafting, jazdę na nartach oraz zwiedzać zabytki. W regionach tych ogółem jest 29 miejscowości (ekosajty), w których znajdują się 72 domy gościnne współpracujące $\mathrm{z}$ nadmienionym centrum informacji turystyki ekologicznej. Gospodarze oferują turystom zakwaterowanie oraz wyżywienie. Liczba miejsc noclegowych w domach jest zróżnicowana, zazwyczaj od 2 do 6 lub od 4 do 12. Są ponadto oferowane alternatywne rodzaje noclegów, np. w jurcie lub namiocie. Ceny wahają się w zależności od rodzaju usług i wynoszą od 1000 tenge (5 euro) do 6000 tenge (30 euro) za jeden dzień pobytu.

Tabela 2. Wielkość i struktura agroekoturystyki w Ekonomicznych Regionach Kazachstanu (ERK)

\begin{tabular}{|c|c|c|c|c|c|c|c|c|}
\hline \multirow{3}{*}{ ERK } & \multirow{3}{*}{ Obwody } & \multirow{3}{*}{$\begin{array}{l}\text { Liczba miejsco- } \\
\text { wości oferują- } \\
\text { cych agroeko- } \\
\text { turystykę }\end{array}$} & \multicolumn{5}{|c|}{ Domy gościnne i miejsca noclegowe } & \multirow{3}{*}{$\begin{array}{l}\text { Alterna- } \\
\text { tywne } \\
\text { typy } \\
\text { noclegu }\end{array}$} \\
\hline & & & \multirow{2}{*}{$\begin{array}{l}\text { ogółem } \\
\text { domy }\end{array}$} & \multicolumn{4}{|c|}{$\begin{array}{c}\text { rozkład miejsc } \\
\text { noclegowych }\end{array}$} & \\
\hline & & & & $2-6$ & $6-10$ & $4-12$ & inny & \\
\hline \multirow[b]{2}{*}{ Południowy } & Ałmaty & 6 & 22 & 5 & 6 & 11 & 0 & - \\
\hline & Południowy & 7 & 14 & 5 & 3 & 3 & 3 & $\begin{array}{l}\text { jurta, } \\
\text { namiot }\end{array}$ \\
\hline Wschodni & Wschodni & 5 & 12 & 7 & 2 & 2 & 1 & jurta \\
\hline Północny & Akmoła & 5 & 9 & 4 & 0 & 4 & 1 & pensjonat \\
\hline Centralny & Karaganda & 3 & 12 & 6 & 0 & 0 & 6 & pensjonat \\
\hline Zachodni & Mangislak & 3 & 3 & 0 & 0 & 0 & 3 & namiot \\
\hline Ogółem & 6 & 29 & 72 & 27 & 11 & 20 & 14 & - \\
\hline
\end{tabular}

Źródło: opracowanie własne na podstawie www.eco-tourism.kz.

Pobyt $\mathrm{w}$ gospodarstwach wiejskich pozwala turystom poznać wiejski styl życia oraz kulturę lokalnych społeczności. W jednej wsi można np. zobaczyć produkcję filcu oraz wyrób z niego artykułów używanych w gospodarstwie, i przy okazji zakupić upominki z tego towaru. W innej wsi, gdzie jest prowadzona od 10 lat farma strusi, przyjeżdżający tu turyści krajowi i zagraniczni mogą zakupić jaja, pióra oraz wygarbowane skóry tych ptaków (fot. 1). Jeszcze inne wsie są dobrymi miejscami dla wypadów pieszych, rowerowych i innych do różnych atrakcji przyrodniczych (góry, jaskinie, rezer- 
waty) oraz antropogenicznych (historycznych lub współczesnych). W okresie letnich wakacji do omawianych miejscowości są kierowani studenci i wolontariusze różnych turystycznych organizacji. Wykonane przez nich zdjęcia, filmy i inne materiały służą do przygotowania broszur informacyjnych, reklamowych, przewodników, map czy stron internetowych.
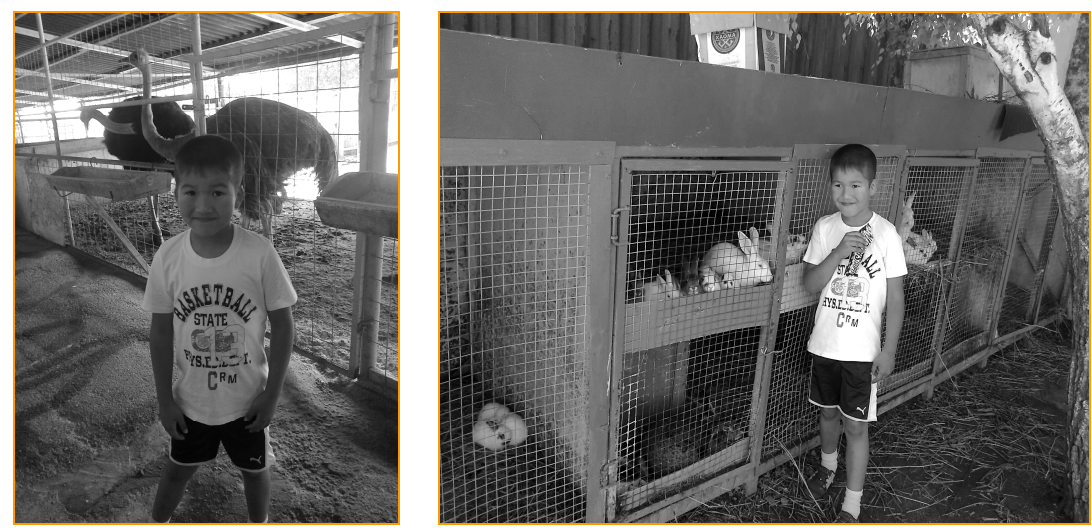

Fotografia 1. Ferma strusiów

(Autor: A. Uaisowa)

Zainicjowany w 2005 r. program rozwoju agroekoturystyki został opracowany także na lata 2010-2014. Organizacyjnie i finansowo bilansuje się dodatnio. Płatności za usługi zakwaterowania, wyżywienia i inne odbywają się zwykle na miejscu, w formie gotówki trafiającej bezpośrednio do właścicieli gospodarstw agroekoturystycznych lub lokalnego koordynatora. Zdobyte $\mathrm{w}$ ten sposób fundusze $\mathrm{w}$ większości pozostają $\mathrm{w}$ danych miejscowościach i przyczyniają się do ich rozwoju oraz wiejskich społeczności (www.eco-tourism.kz).

\section{Rekomendacje wynikające z polskich doświadczeń}

W Polsce agroturystyka rozwija się już prawie ćwierć wieku, czyli co najmniej 15 lat dłużej aniżeli w Kazachstanie. Zarówno czas, jak i uwarunkowania społeczno-kulturowe sprzyjają istnieniu bardzo wielu różnic między omawianymi krajami. Podobieństw jest natomiast zdecydowanie mniej, więc 
warto skupić się na ich analizie, gdyż wydaje się, że na tej podstawie można budować bazę określonych rekomendacji.

Jednym z ważniejszych podobieństw wydaje się być impuls idei rozwoju agroturystyki. W obu omawianych krajach został on wyraźnie zaczerpnięty od państw już dużo wcześniej doświadczonych w tej tematyce. Ich wzorem nakreślono nowy sposób kreowania ruchu turystycznego na wsi, zgodnie ze specyfiką swojego kraju, ale na ogólnie sprawdzonych zasadach. Jedną $\mathrm{z}$ nich jest ścieżka kształcenia. Polega ona na tym, że najpierw kształci się kadry liderów, którzy następnie szkolą mieszkańców wsi. Wraz z tym w terenie idą konkretne działania, czyli organizowanie gościnnych kwater i oferty wypoczynkowej. W obu omawianych krajach od chwili wprowadzenia idei agroturystyki na tej ścieżce odgrywały dużą rolę instytucje państwowe, często pełniące funkcję drogowskazów, a nawet parasola ochronnego dla zainteresowanych jej rozwojem. Można więc mówić, że cechą wspólną opisywanych krajów jest instytucjonalna droga rozwoju agroturystyki. W Polsce wyznaczyły ją instytucje państwowe ${ }^{3}$, często współpracujące z odpowiednimi sobie podmiotami z państw Europy Zachodniej. W Kazachstanie jest to jedna instytucja (centrum informacji o zasobach ekoturystyki), która prowadzi całokształt działań dotyczących planowania, szkolen, marketingu i innych.

Z polskich doświadczeń wynika, że instytucja (podmiot przewodni) $\mathrm{w}$ rozwijaniu agroekoturystyki w Kazachstanie powinna być przygotowana na pojawienie się innych, konkurencyjnych podmiotów zabiegających o „liderowanie". Wówczas będzie on zmuszony do podjęcia działań utrzymania swego przywództwa. Sytuacja taka, pozornie groźna, zwykle sprzyja ukształtowaniu się grupy podmiotów autentycznie zainteresowanych rozwojem agroekoturystyki i powstaniu samorządu tej branży, począwszy od poziomu lokalnego, przez regionalny po krajowy, co miało miejsce $\mathrm{w}$ Polsce. Samorząd taki będzie mógł kształtować w Kazachstanie wielkość i jakość agroekoturystyki odpowiednio do zapotrzebowania $w$ terenie oraz wymagań turystów. Będzie reprezentantem swoich interesów wobec państwowej struktury administracyjnej odpowiedzialnej za rozwój turystyki na obszarach chronionych przyrodniczo. Poza tym należy podkreślić, że rozwój agroekoturystyki powinien być systematycznie monitorowany poprzez odpowiednie badania naukowe. Wzajemna współpraca praktyków i teoretyków

\footnotetext{
${ }^{3}$ Odpowiednie ministerstwa ds. rolnictwa i turystyki, centralne i regionalne ośrodki doradztwa rolniczego, gminy.
} 
jest tu niezmiernie ważna. Jedna strona dostarcza wiedzy teoretycznej, pokazuje szanse, ale i zagrożenia wynikające z przyjętych koncepcji rozwoju. Druga strona (praktycy) dostarcza ciągłych impulsów do badań. Im ściślejsza taka współpraca, tym lepiej dla rozwoju tej formy turystyki, opartej na kapitale społecznym.

Warto zaznaczyć, że proces edukacji mieszkańców wsi zainteresowanych usługami turystycznymi rozpoczął się w Kazachstanie - podobnie jak w Polsce - od szkoleń i kursów podstawowych. Doświadczenia polskie pokazują, że edukacja ta będzie podlegać ewolucji. Będzie to miało swój wyraz w stopniowym przejściu do fazy kształcenia o profilu zaawansowanym oraz specjalistycznym. Dotychczasowe szkolenia i kursy będą musiały być zastąpione profesjonalnym kształceniem, także w szkołach różnego typu i na różnych poziomach. Im szybciej i szerzej zostaną podjęte odpowiednie działania edukacyjne, tym większa szansa na budowę interesującej oferty agroekoturystycznej i na jej zwiększoną dynamikę.

Wachlarz różnych rekomendacji dla kazachskiej agroturystyki można generalnie odnieść do jednej płaszczyzny, czyli edukacyjnej. Ma ona ogromny wpływ na pozostałe płaszczyzny agroturystyki, m.in. organizacyjną, marketingową, ekonomiczną, kulturową czy społeczną. Wszystkie powinny być wspierane systematycznymi badaniami oraz wiedzą naukową.

\section{Zakończenie}

Podsumowując całość omawianego zagadnienia należy zwrócić uwagę na duży potencjał turystyczny Kazachstanu, zwłaszcza ekoturystyczny, który sprzyja prowadzeniu naukowych rozważań nad turystyką wiejską i agroturystyką przez pryzmat turystyki ekologicznej. Podejście to wynika także z umiarkowanych zasobów rolniczych tego kraju. Bardzo duże zasoby przyrodnicze dają szeroki wachlarz dla różnych "odcieni” turystyki ekologicznej, takich jak: agroekoturystyka czy turystyka przyrodnicza. W kazachskiej literaturze przeważa pogląd, że formy turystyki ekologicznej, które są rozwijane w oparciu o kapitał lokalnej społeczności, dają szanse nie tylko na dodatkowe źródło dochodów, ale także na utrzymanie produkcji rolniczej, osadnictwa wiejskiego i tradycyjnego sposobu życia wsi. Nadzieje te są wiązane $\mathrm{z}$ faktem, że znaczna część ludności żyjącej w miastach ma krewnych na wsi, których okresowo odwiedza i w ten sposób sprzyja rozwojowi 
różnych form turystyki na terenach wiejskich. Ponadto $\mathrm{z}$ roku na rok znaczący udział ma turystyka zagraniczna, dla której omawiana oferta jest interesująca.

Należy podkreślić, że impuls do rozwoju agroekoturystyki w Kazachstanie nadali akademicy, którzy pierwsi zaczęli pisać na ten temat różne opracowania. Naukowcy korzystają ponadto z doświadczeń innych krajów, w tym bardzo odległych zarówno w sensie fizycznym, jak i kulturowym, czego przykładem może być Polska.

Można przypuszczać, że tak jak w Europie agroturystyka rozwijała się falami (pierwsza fala rozwoju w XX w. to lata 50.-60., druga - 70.-80., trzecia - lata 90.), w wyniku których ukształtowali się jej liderzy (np. Francja, Niemcy, Austria), tak proces ten może być podobny dla Azji Środkowej. Podjęte działania wskazują, że Kazachstan ma szanse zostać liderem rozwoju agroturystyki w tym regionie świata, a czerpanie doświadczeń od krajów europejskich może temu wyraźnie się przysłużyć.

\section{BIBLIOGRAFIA}

ABILDINOW P.S., OSTAPENKO I.I., 2013, Razvitie agroturizma v Almatinskoy oblasti (Paзbuтиe aгpo mypuзма в алматинской области), „Сельское, лесное и водное хозяйство”, № 3.

AlEKSANDROWA A.U, 2008, Geographia turizma (География туризма), Knorus, Moskwa.

BIRZHAKOW M.B., 2000, Vedenie v turism (Введение в туризм), Gerda, St. Petersburg.

ERDAVLETOW S.R., KOSHKINBAEWA U.T, 2004, Enoturism - novi factor activizacy selskih territori (Энотуризм - новый фактор активизаиии сельских территорий), „Vestnik KazNU”, seria geogr. № 1 (18), s. 154-162.

ERDAVLETOW S.R., KOSHKINBAEWA U.T, 2005, Turizm i aktivizacia naselenia selskih territori (Туризм и активизация населения сельских территорий), [w:] Reali i prohnozi demograficheskogo razvitia Eurasjiskogo prostranstoa: mezhdunarodna nauchno-prakticheskaya konferencya, 15-16 may, Raritet, Almaty, s. 75-81.

ERZHANOWA S.K., 2011, Rol predprinimatelstwa v razvity selskogo turizma (Рольпредпринимательства в развитии сельского туризма), Вестник КарГУ, Караганда.

IDIRIS Zh.N., 2013, Socialno-economiceskaya rol i perspectivi razvitia agrotuirsma v Kazakhstane (Counuльно-экономическая роль и перспективы развития агротуризма в Казахстане), Glowal, http:// www.group-global.org.

Kazakhstan: Ulttik enciklopedia (Қазақ̧стан:Ұлттық Энииклопедия), 2003 Almaty, s. 253-255, 268, 270, $272,275-276,330$.

Kulturnoye nasledye Kazakhstana (enciklopedicheskiy slowar A-Я), (Культурное наследие Казахстана энции-клопедический словарь А-Я), 2005, Aruna, Almaty.

Programma po razvitiu agropromislennogo kompleksa v Respublike Kazachstan na 2013-2020 godi) (Программа по развитию агропромышленного комплекса в Республике Казахстан на 20132020 годы), „Агробизнес - 2020", 18.02.2013, № 151.

TEMiRbulatOWA M.A., 2010, Teoria i praktika agroturizma: polskij opyt (Теория и практика агротуризма: польский опыт), Poznań, ss. 315. 
TusupbeKOWA G.M., 2008, Derevenski turism, kak chast obshego turizma (Деревенский туризм, как часть общего туризма), „Тurist”, № $4 / 5$.

UAISOWA A., 2008, Osobennosti razvitia selskogo turizma v Respublike Kazakhstan (Особенности развития сельского туризма в Республике Казахстан), [w:] Mezhdunarodnaya nauchno-prakticeskaya konferencia, "Auezov i aktualne problemy kazakhovedenia", Shymkent.

UAISOWA A., 2012a, Predposilki razvitia agroturizma (Предпосылки развития агротуризма), [w:] Каz NPU imeni Abay, Materiali Mezhdunarodnaya nauchno-practiceskaya konferencia "Aktualne prioritetnye napravlenya geograficeskoy nauki dlia ustoycivogo turizma", Almaty.

UAISOWA A., 2012b, Razvitia agroturistkoy fermi: obosnowanie predposolok, (Разиития агротуристкой фермы: обоснование предпосылок), [w:] Mezhdunarodni Forum molodih uchenih stran GIS, "Molodezh v nauki - 2012", Almaty.

UVAZHANOWA M., 2008, Est li perspektivi selskogo turizma v Respublike Kazakhstan (Ecmь ıи nерсnективы развития сельского туризма в Республике Казахстан), [w:] Mezhdunarodnaya nauchnoprakticeskaya konferencia, „Auezov i aktualnie problemy kazakhovedenia”, Shymkent.

WOJCIECHOWSKA J., UAISOWA A., 2013, Vozhmoznosti primemenia polskogo opyta razvitia agroturizma $v$ Kazakhstane (Возможности применения польского опыта развития агротуризма в Казахстане), [w:] Materialy respublikanskoy nauchno-praktichieskoy konferenci "KazYMOiMA w mezhdunarodnom nauchno-obrazavatelnom prostranstve: 70 let razvitia", Kazakhsky Universitet, Almaty, s. 184-189.

ZARĘBA D., 2000, Ekoturystyka. Wyzwania i nadzieje, PWN, Warszawa.

www.eco-tourism.kz/eco3.html.

www.e-history.kz/ru/contents/list/88.

www.kit.gov.kz.

www.stat.kz.

\section{DEVELOPMENT OPPORTUNITIES OF AGRITOURISM IN KAZAKHSTAN}

Key words: tourism, agritourism, ecotourism, Kazakh, Poland

\section{Summary}

In the article the authors consider the development of agritourism in Kazakhstan and they show the prospect of using of Polish experiences. The main content of the article consists of three parts. The first part relates to the characteristics of natural and socio-cultural resources which are essential for the development of tourism in Kazakhstan. The second part presents the state of development of agritourism in Kazakhstan and the third contains the Polish experiences in the form of recommendations which may be relevant to the country described. The authors conclude that natural and socio-cultural resources of Kazakhstan show a high potential for tourism development, where natural tourism is particularly significant, and which provides a wide range of opportunities to develop various shades of ecotourism. Agritourism (rural tourism) is considered here as a part of ecotourism. In the early 2000's academics gave a impulse to development of the agritourism and practitioners organized a network of guest farms on the territory of Kazakhstan. Actions taken show that Kazakhstan has a chance to become a leader in the agritourism development in Central Asia, and the study of the European experiences can help in this. 